\title{
Decreased vascular supply leads to higher numbers of NADPH diaphorase amacrine cells in the degenerating
}

\section{mouse retina}

\author{
Christian-Albrecht May" \\ Department of Anatomy, University Hospital Carl Gustav Carus, Dresden, Germany
}

\begin{abstract}
NADPH diaphorase/neuronal nitric oxide synthase stained amacrine cells (NAC) are supposed to interact with the retinal vasculature. To study this hypothesis, the retinae of two different mouse strains and their controls were stained using the NADPH diaphorase technique labelling NAC and vessels. In the retina degeneration (rd) mouse, the total number of NAC in the first weeks during early retinal degeneration was slightly reduced. The number persisted in older animals and did not show the decrease described in normal mice. In the Norrie disease (nd) mouse, early vascular malformation lead to increased numbers of NAC. Although the progress of neural remodelling in the degenerated retina leads to a continuous loss of neurons in general, the NAC persist in higher numbers in parallel with a reduced vascular bed.
\end{abstract}

\section{Brief report}

Close association between the retinal vasculature and NADPH diaphorase (NADPH-d)/nNOS stained amacrine cells (NAC) were reported for the rat and primate [1,2] and a regulatory function of these cells on retinal microcirculation discussed. This is supported by physiological findings concerning the intensity of relaxation measured in retinal vessels $[3,4]$.

To further study the interdependency between NOS positive amacrine cells and vasculature, two different kinds of retinal degeneration were investigated. One showed degenerative and neovascular processes after normal vascular development ( $r d$ mouse $[5,6])$, the other primary vascular irregularities (nd mouse [7]). Retina whole mounts from rd, nd, and C57BL/6 mice at various ages were stained for NADPH-d as described previously [8]. All animals were kept according to the Declaration of Helsinki and the local rules for animal research.

In the rd mouse retina, first NAC somata were detected at $\mathrm{P} 3$ in the inner cytoblast layer similar to controls. At P14, the number of NAC was only $80 \%$ of that counted in control animals (Table 1). However, this number persisted during ageing resulting in an elevated number of NAC somata at 3 months of age and older (Table 2).

First changes of the retinal vasculature were obvious at P14. The outer vascular layer continuously degenerated and was almost completely absent at 6 weeks of age. Sprouting vessels in the retinal pigment epithelium (RPE) layer were noted at four weeks of age, rising in number and size with age. From eight weeks on, RPE cells were found around vessels of the inner vascular layers indicating migration along the vasculature.

Combining vascular and NAC alterations in the rd mouse, some relation between both structures can be stated. The first onset of retinal degeneration after P7 [5] lead to decreased numbers of NAC. Vascular degeneration paralleled stabilization of elevated NAC number during further retinal degeneration. Neovascularizations did not alter the increased NAC level.

In the nd mouse model, homozygous male nd mice revealed a higher number of NAC cells than age-matched controls at all ages (Table 1). Heterozygous female nd mice showed normal numbers of NAC in younger ages, but older animals showed increased numbers compared to age-matched controls indicating late-onset changes not described previously (Tables 1 and 2).

Homozygous male nd mice showed only one layer of retinal vessels located in the innermost layer. The vessels stained weakly for

Table 1. Total number of NADPH diaphorase stained amacrine cells (total number in the retina) at different ages. Each number represents one retina of one animal.

\begin{tabular}{|c|c|c|c|c|}
\hline age & \multicolumn{2}{|l|}{ rd } & \multicolumn{2}{|r|}{ control } \\
\hline 3 days & \multicolumn{2}{|l|}{22} & \multicolumn{2}{|c|}{$22,25,19$} \\
\hline 1 week & \multicolumn{2}{|l|}{722} & \multicolumn{2}{|c|}{872,868} \\
\hline 2 weeks & \multicolumn{2}{|c|}{$868,749,719$} & \multicolumn{2}{|c|}{$1029,1010,1004$} \\
\hline 3-4 weeks & \multicolumn{2}{|c|}{$808,765,746,837$} & \multicolumn{2}{|c|}{$792,740,698$} \\
\hline 6 weeks & \multicolumn{2}{|c|}{758,725} & \multicolumn{2}{|c|}{$649,617,611$} \\
\hline 3 months & \multicolumn{2}{|l|}{724} & \multicolumn{2}{|c|}{638,615} \\
\hline age & nd (homozygous) & \multicolumn{2}{|c|}{ nd (heterozygous) } & control \\
\hline 3-4 weeks & 953,877 & \multicolumn{2}{|c|}{711} & $792,740,698$ \\
\hline 3 months & $745,733,729$ & \multicolumn{2}{|c|}{683} & 638,615 \\
\hline $6-8$ months & $794,783,755,726,685$ & \multicolumn{2}{|c|}{$733,712,674$} & $616,546,524$ \\
\hline$\geq 12$ months & 712 & \multicolumn{2}{|c|}{708} & 594 \\
\hline
\end{tabular}

Correspondence to: Dr. Christian Albrecht May, Department of Anatomy, University Hospital Carl Gustav Carus, Fetschertstr. 74, D-01307, Dresden, Tel: +49-351-4586105; Fax: +49-351-4586303; E-mail: Alrecht.May@mailbox.tu-dresden.de

Key words: mouse, retina, norrie disease, degeneration, amacrine cell, nitric oxide synthase

Received: April 05, 2017; Accepted: April 25, 2017; Published: April 27, 2017 
Table 2. NADPH diaphorase positive amacrine cells in the peripheral retina (measuring field: $1 \mathrm{~mm}^{2}$ ) at different ages. Mean values \pm standard deviation $(\mathrm{n}=$ number of animals).

\begin{tabular}{|c|c|c|c|c|}
\hline age & rd & nd homozygous & nd heterozygous & control \\
\hline 3 months & $18.4 \pm 1.7(n=4)$ & $25.8 \pm 4.1(n=4)$ & $17.4 \pm 1.2(n=6)$ \\
\hline $6-8$ months & $20.9 \pm 3.1(n=3)$ & $21.1 \pm 2.8(n=5)$ & $23.1 \pm 2.5(n=6)$ \\
\hline$>12$ months & $20.6 \pm 2.2(n=5)$ & $16.4 \pm 1.0(n=2)$ & $26.6 \pm 1.7(n=3)$ \\
\hline
\end{tabular}

NADPH-d. In addition, persistent vitreous vessels were found in all whole mounts examined. The endothelial cells of these vessels stained strongly for NADPH-d. Heterozygous nd mice showed a normal developed tree-layered retinal vasculature at 3 weeks of age with normal NADPH-d staining behaviour. At 8 months of age, the vascular staining was reduced, the outer vascular layers disappeared and only the inner layer of the capillary bed remained present.

Combining vascular and NAC alterations in the nd mouse, the lack of retinal vascularization in homozygous animals lead to an increase of NAC which persisted during retinal degeneration. Heterozygous mice showed a delayed degeneration with normal development of the retinal vasculature and NAC. When first changes were noted in the vasculature, also the number of NAC was increased and remained so during further degeneration.

During the progress of neural remodelling in the degenerated retina, a continuous loss of neurons has been described previously [9]. Our findings support that NAC remain constantly present (similar to a report in RCS rat eyes [10]) and are even increased in number. NAC develop independent from retinal vascularization but their persistence in higher numbers than in the controls shows correlation to the reduced vascular stage of the retina. Retinae with increase of vascular supply like in diabetes show reduced numbers of NAC [11]. Since blood supply is correlated with the activity of the retina, light-dependent changes in NAC [12] might explain their modulating role for both, the neuronal aspects of the retina and the retinal vasculature. Further studies have to address the functional connection between the named systems.

\section{References}

1. Roufail E, Stringer M, Rees S (1995) Nitric oxide synthase immunoreactivity and
NADPH diaphorase staining are co-localised in neurons closely associated with the vasculature in rat and human retina. Brain Res 684: 36-46. [Crossref]

2. Kolb H, Yan XX, deKorver L (1996) Amacrine cells of the primate retina that contain NADPH diaphorase: colocalization with other neurotransmitters and circuity. Invest Ohthalmol Vis Sci 37: S139.

3. Donati G, Pournaras CJ, Munoz JL, Poitry S, Poitry-Yamate CL, et al. (1995) Nitric oxide controls arteriolar tone in the retina of the miniature pig. Invest Ophthalmol Vis Sci 36: 2228-2237.

4. Toda N, Nakanishi-Toda M (2007) Nitric oxide: ocular blood flow, glaucoma, and diabetic retinopathy. Prog Retin Eye Res 26: 205-238.[Crossref]

5. Blanks JC, Johnson LV (1986) Vascular atrophy in the retinal degenerative rd mouse. $J$ Comp Neurol254: 543-553.[Crossref]

6. Wang S, Villegas-Pérez MP, Vidal-Sanz M, Lund RD (2000) Progressive optic axon dystrophy and vacuslar changes in rd mice. Invest Ophthalmol Vis Sci 41: 537-545. [Crossref]

7. Richter M, Gottanka J, May CA, Welge-Lüssen U, Berger W, et al. (1998) Retinal vasculature changes in Norrie disease mice. Invest Ophthalmol Vis Sci 39: 2450-2457. [Crossref]

8. May CA, Mittag T (2004) Neuronal nitric oxide synthase (nNOS) positive retinal amacrine cells are altered in the DBA/2NNia mouse, a murine model for angle-closure glaucoma. J Glaucoma 13: 496-499.[Crossref]

9. Marc RE, Jones BW, Watt CB, Strettoi E (2003) Neural remodeling in retinal degeneration. Prog Retin Eye Res 22: 607-655.[Crossref]

10. Sharma RK, Warfvinge K, Ehinger B (2001) Expression of nitric oxide synthase during the development of RCS rat retinas. Ophthalmologica 215: 222-228.[Crossref]

11. Goto R, Doi M, Ma N, Semba R, Uji Y (2005) Contribution of nitric oxide-producing cells in normal and diabetic rat retina. Jpn J Ophthalmol49: 363-370.[Crossref]

12. Pang JJ, Gao F, Wu SM (2010) Light responses and morphology of bNOSimmunoreactive neurons in the mouse retina. J Comp Neurol518: 2456-2474.[Crossref]

Copyright: (C2017 May CA. This is an open-access article distributed under the terms of the Creative Commons Attribution License, which permits unrestricted use, distribution, and reproduction in any medium, provided the original author and source are credited. 